\title{
KONTRIBUSI DANA PIHAK KETIGA TERHADAP RENTABILITAS EKONOMIS (STUDI KASUS DI PT BANK MUAMALAT INDONESIA)
}

\author{
Agung Budi \\ Dosen Fakultas Ekonomi dan Bisnis Program Studi Manajemen \\ Universitas Muhammadiyah Tangerang
}

\begin{abstract}
ABSTRAK
This research aims to figure out how significant is the effect of The Third Party Funds (the research focuses on the Deposit of Mudharabah, Mudharabah Savings, and the Wadi'ah Giro) towards Economical Profitability at PT. Bank Mu'amalat Indonesia (BMI). This research is a kind of a descriptive research through correlational regression method. It aims to figure out how significant is one or more than one variables may give the influence towards other variables. The result of this research shows that The Third Funds does not have any significant effect towards the Economical Profitability with the gained correlational value $31,4 \%$. It goes without saying, $68,6 \%$ of Economical Profitability is influenced by other variables which are not identified in this research.
\end{abstract}

Kata Kunci : Third Fund Party, Economic Rentability

\section{PENDAHULUAN}

Perkembangan bank umum
syariah di Indonesia senantiasa
meningkat dari tahun ke tahun, karena
didukung oleh pemerintah. Berbagai
macam kebijakan dikeluarkan oleh
pemerintah dalam rangka
pengembangan sistem perbankan
syariah. Kebijakan yang dikeluarkan
pemerintah antara lain:

1. Undang-undang No. 10 Tahun 1998 tentang Perubahan Undang-undang No. 7 Tahun 1992 tentang Perbankan, yang didalamnya tercantum pasal-pasal yang membuka peluang bagi pengembangan bank syariah secara lebih luas. Pasal-pasal tersebut dituangkan dalam Surat Keputusan Direktur Bank Indonesia yang

mengatur seluruh kegiatan operasional bank syariah, yaitu :

a. Surat Keputusan Direktur Bank Indonesia No. 32/33/Kep/Dir tentang Bank Umum;

b. Surat Keputusan Direktur Bank Indonesia No. 32/34/Kep/Dir tentang Bank Umum Berdasarkan Prinsip Syariah.;

c. Surat Keputusan Direktur Bank Indonesia No. 32/35/Kep/Dir tentang Bank Perkreditan Rakyat Syariah;

2. Undang-undang No. 23 Tahun 1999 tentang Bank Indonesia yang mengamanatkan Bank Indonesia untuk mempersiapkan berbagai perangkat ketentuan yang mengakomodir keperluan Perbankan Syariah. 
3. Peraturan Bank Indonesia No.2/7/PBI/ 2000 tentang Giro Wajib Minimum dalam Rupiah dan Valuta Asing bagi Bank Umum yang melakukan usaha berdasarkan prinsip syariah.

4. Peraturan Bank Indpnesia No.2/8/PBI/ 2000 tentang Pasar Uang Antar Bank berdasarkan prinsip syariah.

5. Peraturan Bank Indonesia No.2/9/PBI/ 2000 tentang Sertifikat Wadiah Bank Syariah.

PT. Bank Muamalat Indonesia Tbk (BMI) merupakan salah satu bank umum yang lahir setelah dikeluarkannya Pakto 1988. Dalam melaksanakan kegiatan operasionalnya, BMI menggunakan prinsip bagi hasil atau prinsip syariah dalam proses penciptaan maupun pembagian keuntungan.

Dengan sistem bagi hasil yang digunakan, maka BMI harus dapat menatalaksanakan dana yang tersedia secara profesional sehingga memberikan keuntungan yang optimal dan pelayanan yang baik terhadap nasabah. Penggunaan dan pengalokasian dana yang kurang efektif dan efisien mengakibatkan rendahnya tinggat pengembalian dan tingkat profitabilitas yang diperoleh oleh perusahaan.

Untuk menjaga kondisi-kondisi yang akan menghambat kelangsungan kegiatan operasional BMI, diperlukan analisis laporan keuangan. Analisis ini difokuskan pada analisa penggunaan dan pengelolaan dana pihak ketiga terhadap rentabilitas, yaitu mengukur tingkat keefisienan dan keefektifan penggunaan dan pengelolaan dana pihak ketiga serta pengaruhnya terhadap tingkat kemampulabaan yang dicapai oleh bank yang bersangkutan.
Data perkembangan hasil penjualan jasa yang dilakukan oleh Bank antara tahun 2010 sampai dengan tahun 2015, rata-rata perkembangan pendapatan operasional yang dihasilkan BMI sebesar 20,80\%. Kenaikan tertinggi terjadi pada tahun 2014 sebesar 67,11\%, sedangkan penurunan terbesar terjadi pada tahun 2015 sebesar 69,45\%. Sedangkan perkembangan pendapatan non operasional yang dihasilkan BMI rata-rata sebesar $10.970,09 \%$. Kenaikan tertinggi terjadi pada tahun 2015 sebesar $65.801,38 \%$, sedangkan penurunan terjadi pada tahun 2012 , yaitu $87,98 \%$ dan 2013, yaitu 51,97\%.

Total aktiva yang digunakan langsung dalam operasi bank yang bersangkutan, serta jumlah biaya yang dikeluarkan oleh BMI selama periode 2010-2015 serta perkembangan aktiva operasi tahun 2010 sampai dengan tahun 2015 cenderung mengalami penurunan secara prosentase, dengan rata-rata perkembangannya sebesar $22,99 \%$. Pada tahun 2011, 2012 dan 2015 perkembangan aktiva operasi mengalami peningkatan di atas rata-rata, yaitu $60,79 \%, \quad 29,90 \%$ dan $65,23 \%$. Sedangkan, pada tahun 2014 pekembangan aktiva operasi mengalami penurunan terbesar yaitu 27,66\%.

Perkembangan dana pihak ketiga serta dana pihak ketiga produktif BMI cenderung mengalami penurunan dari tahun ke tahun dengan dengan perkembangan rata-rata sebesar 30,88\%. Penurunan terbesar terjadi pada tahun 2014, yaitu $15,44 \%$.

Perkembangan dana pihak ketiga produktif BMI mengalami penurunan dari tahun ke tahun dengan perkembangan rata-rata sebesar $56,34 \%$. Peningkatan terbesar terjadi pada tahun 
2011 sebesar 278,14\%, sedangkan penurunan terbesar terjadi pada tahun 2015, yaitu 30,85\%.

Perkembangan dana pihak ketiga produktif terhadap total dana pihak ketiga mengalami kecenderungan meningkat, dengan perkembangan ratarata sebesar 3,00\%. Perkembangan terbesarterjadi pada tahun 2013 yaitu $4,26 \%$, sedangkan perkembangan terkecil terjadi pada tahun 2015, yaitu $1,99 \%$.

Perkembangan biaya yang diberikan oleh Bank Muamalat Indonesia selama periode 2010-2015, serta margin laba yang diperoleh dalam Pembiayaan yang dilakukan oleh perusahaan mengalami kenaikan selama periode tersebut walaupun secara persentase mengalami penurunan. Perkembangan rata-rata pembiayaan adalah $16,83 \%$, dimana perkembangannya pada tahun 2011 dan 2013 berada diatas rata-rata yaitu sebesar $51,61 \%$ dan $47,11 \%$. Sedangkan, penurunan terbesar terjadi pada tahun 2015 yaitu sebesar 6,50\%.

Perkembangan rugi laba Bank Muamalat Indonesia, rentabilitas ekonomis dan rentabilitas modal sendiri mengalami penurunan secara persentase, dengan rata-rata penurunan sebesar 240,68\%. Penurunan terbesar terjadi pada tahun 2014, yaitu sebesar $1.617,00 \%$. Pada periode yang sama rentabilitias ekonomis perusahaan mengalami kecenderungan menurun dengan rata-rata penurunan sebesar $3,66 \%$. Sedangkan rentabilitas perusahaan juga mengalami kecenderungan menurun dengan ratarata penurunan sebesar $29,03 \%$.

\section{KAJIAN TEORITIS DAN HIPOTESIS PENELITIAN}

Bambang Riyanto

menyatakan Rentabilitas ekonomis adalah perbandingan anatar laba usaha dengan modal sendiri dan modal asing yang digunakan untuk menghasilkan laba tersebut dan dinyatakan dalam prosentase. Oleh karena itu pengertian rentabilitas sering digunakan untuk mengukur efesiensi penggunaan modal di dalam suatu perusahaan dengan seluruh modal yang bekerja di dalamnya untuk menghasilkan modal.

Dalam membahas dana pihak ketiga pada penelitian ini, penulis hanya membatasinya pada 3 hal saja, yaitu :

1. Deposito Mudharabah yang merupakan simpanan nasabah yang penarikannya hanya dapat dilakukan pada waktu tertentu dengan prinsip Al-mudharabah. Deposito mudharabah memberikan bagi hasil kepada nasabah berdasarkan nisbah (rasio bagi hasil) yang disepakati. Jenis produknya adalah fulinves.

2. Tabungan Mudharabah merupakan simpanan nasabah dalam bentuk tabungan dengan prinsip Almudharabah. Tabungan Mudharabah memberikan imbalan bagi hasil kepada nisbah (rasio bagi hasil) yang disepakati yang disepakati.

3. Giro Wadiah merupakan titipan dana pihak ketiga berupa simpanan giro dengan menggunakan prinsip Alwadi'ah, yang penarikannya dapat dilakukan setiap saat dengan menggunakan cek, bilyet giro dan pemindah bukuan. Dalam hal ini bank dapat memanfaatkan dana tersebut dengan ijin ataupun tanpa ijin dari nasabah yang bersangkutan untuk membiayai kegiatan operasi 
bank. Seluruh keuntungan atau manfaat yang diperoleh dari penggunaan dana tersebut menjadi milik bank. Atas dasar kebijakan, bank akan memberikan bonus kepada nasabah yang besarnya akan diserahkan kepada bank.

Dalam penelitian ini penulis menggunakan data sekunder yang digunakan untuk keperluan menyusun suatu karya ilmiah dan kemudian menganalisa faktor-faktor yang berhubungan dengan pokok-pokok permasalahan sehingga terdapat suatu kebenaran data-data yang akan diperoleh.

Guna mendukung data dan keterangan-keterangan yang diperlukan dalam penelitian, penulis menggunakan metode dokumentasi melalui penelitian kepustakaan (Library Research), yaitu suatu langkah pengumpulan data dengan menggunakan referensi berupa bukubuku dan karya tulis lainnya. Selain itu penulis juga memperoleh informasi dari internet yang berhubungan dengan bahasan penelitian.

Maman Suherman dan Moch. Irfan Kurnia (2014) menemukan bahwa dana pihak ketiga berpengaruh positif dan signifikan terhadap rentabitlitas sedangkan L. Afriani (2014) menyatakan berpengaruh positif tetapi tidak segnifikan. Karena itu penulis membuat hipoteis sebagai berikut :

H1 : Deposito Mudharabah, Tabungan Mudharabah dan Giro Wadiah berpengaruh positif terhadap Rentabilitas Ekonomis.

L. Mukaromah (2015) dalam penelitiannya menemukan bahwa Deposito Mudharabah berpengaruh positif tetapi tidak signifikan terhadap Rentabilitas sedangkan Mirayanti (2014) menyatakan berpengaruh positif dan signifikan. Karena itu penulis membuat hipoteis sebagai berikut :

H2 : Deposito Mudharabah berpengaruh positif terhadap Rentabilitas Ekonomis.

Santoso (2013) dalam penelitiannya menemukan bahwa Tabungan Mudharabah berpengaruh positif tetapi tidak signifikan terhadap Rentabilitas sedangkan Fima Ekawati (2015) menyatakan berpengaruh positif dan signifikan. Karena itu penulis membuat hipoteis sebagai berikut :

H3: Tabungan Mudharabah berpengaruh positif terhadap Rentabilitas Ekonomis.

Andreasari (2015) dalam penelitiannya menemukan bahwa Giro Wadiah berpengaruh positif dan signifikan terhadap Rentabilitas sedangkan A, Fathurrahman (2012) menyatakan berpengaruh positif tetapi tidak signifikan. Karena itu penulis membuat hipoteis sebagai berikut :

H4 : Giro Wadiah berpengaruh positif terhadap Rentabilitas Ekonomis.

\section{METODE PENELITIAN}

Metode penelitian yang digunakan dalam menganalisis pengaruh Deposito Mudharabah, Tabungan Mudharabah dan Tabungan Wadiah terhadap Rentabilitas Ekonomis adalah mengumpukan data yang kemudian selanjutnya diolah dengan menggunakan software SPSS versi 22. Metode analisis yang digunakan dalam penelitian ini adalah analisis regresi berganda dengan panel data. Panel data atau disebut data longitudinal adalah sekelompok data individual yang diteliti selama rentang waktu tertentu. Pengujian yang 
dilakukan dalam penelitian ini adalah Uji T dan Uji F.

\section{HASIL DAN PEMBAHASAN}

Data penelitian dalam penelitian ini adalah berupa data skunder yang bersumber dari Bank Muamalat Indonesia maupun website perusahaan tersebut. Untuk mempermudah perolehan deskripsi mengenai data penelitian, maka data penulis sajikan dalam satu kesatuan sebagai berikut :

\section{Tabel 1}

Rasio Rentabilitas Bank Muamalat Indonesia Periode 2010-2015

\begin{tabular}{|c|c|c|c|c|c|c|}
\hline \multirow{2}{*}{$\begin{array}{c}\text { Futh } \\
\text { Rersblna }\end{array}$} & \multicolumn{6}{|c|}{ Tatur } \\
\hline & 2 DWu & 311 & 2013 & 24I & 3114 & 7015 \\
\hline Mratshtu & & & & & & \\
\hline$\frac{\text { Enowis }}{\text { Thi }}$ & 2,47 & 2.17 & 09 & $1,6 \pm$ & 67.75 & c59 \\
\hline
\end{tabular}

Berdasarkan table di atas maka rasio yang diperbandingkan pada tahun 2010 adalah 12,70, pada tahun 2011 adalah $(53,51)$, pada tahun 2012 adalah 127,26, pada tahun 2013 adalah $(4044,33)$ dan pada tahun 2015 adalah 101,47 .

Sedangkan analisis pertumbuhan dana pihak ketiga dengan rentabilitas ekonomis dapat dilihat pada table di bawah ini :

Tabel 2

Perkembangan Dana Pihak

Ketiga PT. Bank Muamalat

Indonesia Periode 2010-2015

(Jumlah Dalam Rupiah)

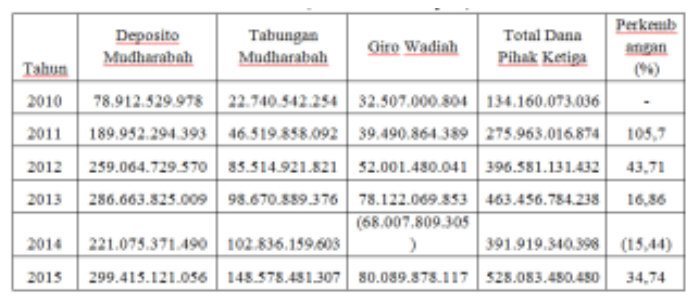

Berdasarkan tabel di atas penulis menganalisa perkembangan Dana Pihak Ketiga pada PT. Bank Muamalat Indonesia. Perkembangan dana pihak ketiga BMI cenderung mengalami penurunan dari tahun ke tahun dengan perkembangan rata-rata sebesar 30,88\%. Penurunan tersebut terjadi pada tahun 2014.

Tabel 3

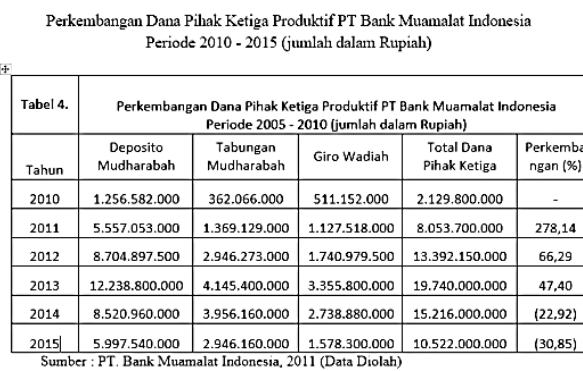

Berdasarkan tabel diatas, perkembangan dana pihak ketiga produktif PT. Bank Muamalat Indonesia mengalami penurunan dari tahun ke tahun dengan perkembangan rata-rata sebesar 56,34\%. Peningkatan terbesar terjadi pada tahun 2011 sebesar $278,14 \%$, sedangkan penurunan terbesar terjadi pada tahun 2015 , yaitu $30,85 \%$.

\section{Tabel 4}

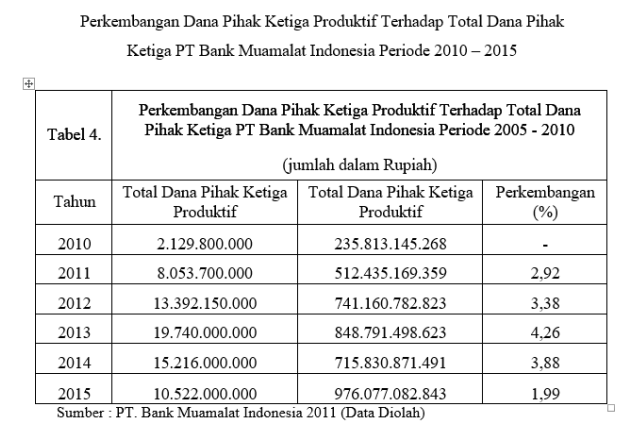

Berdasarkan tabel di atas, perkembangan dana pihak ketiga produktif terhadap total dana pihak ketiga mengalami kecenderungan meningkat, dengan perkembangan ratarata sebesar 3,00\%. Perkembangan terbesar terjadi pada tahun 2013 yaitu 
sebesar $\quad 4,26 \%, \quad$ sedangkan perkembangan terkecil terjadi pada tahun 2015 sebesar 1,99\%.

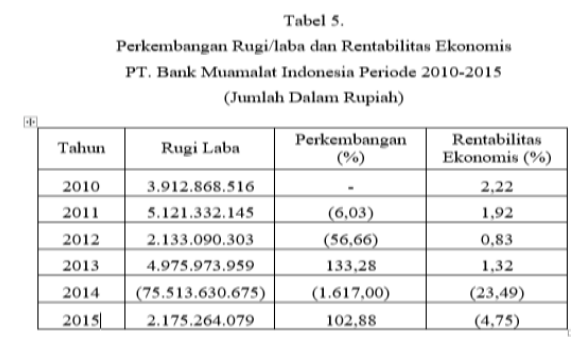

Berdasarkan tabel 5 di atas penulis menganalisa perkembangan Rentabilitas Ekonomis pada PT. Bank Muamalat Indonesia. Perkembangan rugi/laba perusahaan cenderung mengalami penurunan secara persentase, dengan rata-rata penurunan sebesar 240,68\%. Penurunan tersebut terjadi di tahun 2014, yaitu sebesar $1.617,00 \%$. Pada periode yang sama rentabilitas ekonomis perusahaan mengalami kecenderungan menurun dengan ratarata penurunan sebesar $3,66 \%$.

Panel data yang ada setelah dimasukkan ke dalam Software SPSS versi 22 menghasilkan hal-hal sebagai berikut :

Tabel 6.

One-Sample Kolmogorov-Smirnov Test

\begin{tabular}{|ll|r|}
\hline & & $\begin{array}{c}\text { Unstandardized } \\
\text { Residual }\end{array}$ \\
\hline $\mathrm{N}$ & Mean & 6 \\
Normal & .0000000 \\
Parameters & Std. & 23.14716559 \\
$\mathrm{~b}$ & Deviation & .235 \\
Most & Absolute & .161 \\
Extreme & Positive & -.235 \\
Differences & Negative & .575 \\
Kolmogorov-Smirnov Z & .896 \\
Asymp. Sig. (2-tailed) & \\
\hline
\end{tabular}

a. Test distribution is Normal.

b. Calculated from data.
Berdasarkan hasil pada Tabel 6 diatas, menunjukkan bahwa data terdistribusi secara normal. Hal ini ditunjukkan dengan nilai KolmogorovSmirnov hasilnya menunjukkan tingkat signifikansi diatas $\alpha=5 \%$ atau 0,05 yaitu 0,896 , hal ini berarti data yang ada pada semua variabel yang digunakan terdistribusi secara normal.

Tabel 7.

Pengujian

Multikolinieritas

\begin{tabular}{|l|r|c|}
\hline \multirow{2}{*}{ Variabel } & \multicolumn{2}{|c|}{ Collinearity Statistics } \\
\cline { 2 - 3 } & Tolerance & \multicolumn{1}{c|}{ VIF } \\
\hline Tabungan & .110 & 9.098 \\
Mudharabah & & \\
Giro Wadiah & .129 & 7.726 \\
Deposito Mudharabah & .211 & 4.731 \\
\hline
\end{tabular}

Sumber: Data primer yang diolah

Hasil pengujian dalam tabel di atas menunjukkan bahwa semua variabel yang digunakan sebagai prediktor model regresi menunjukkan nilai VIF yang cukup kecil, dimana semuanya berada di bawah 10 dan nilai tolerance semua variabel berada diatas 0,10 . Hal ini berarti bahwa variabel-variabel bebas yang digunakan dalam penelitian tidak menunjukkan adanya gejala multikolinieritas, yang berarti bahwa semua variabel tersebut dapat digunakan sebagai variabel yang saling independen.

Selanjutnya dilakukan perhitungan regresi linear berganda dilakukan untuk mengetahui seberapa besar pengaruh variabel bebas yang meliputi Deposito Mudharabah $\left(\mathrm{X}_{1}\right)$, Tabungan Mudharabah $\left(\mathrm{X}_{2}\right)$ dan Giro Wadi'ah $\left(\mathrm{X}_{3}\right)$ maupun keseluruhan terhadap variabel terikat yaitu rentabilitas ekonomis perusahaan (Y) diringkas sebagai berikut : 
Tabel 8

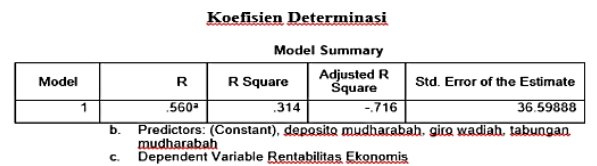

Dari hasil perhitungan regresi dapat diketahui bahwa koefisien determinasi (R Square) yang diperoleh sebesar 0,314 Hal ini berarti 31,4\% Rentabilitas Ekonomis dapat dipengaruhi oleh variabel Deposito Mudharabah, Tabungan Mudharabah dan Giro Wadiah, sedangkan sisanya yaitu 68,6\% Rentabilitas Ekonomis dapat dipengaruhi oleh variabel-variabel lainnya yang tidak diteliti dalam penelitian ini.

Tabel 9

Uij F

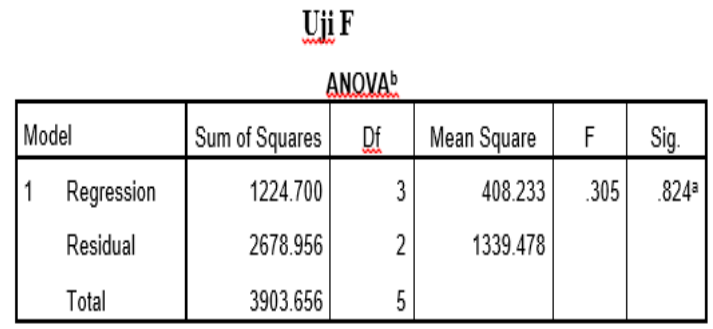

a. Predictors: (Constant), deposito mudharabah, giro wadiah, tabungan mudharabah

b. Dependent Variable: rentabilitas ekonomis

Hasil pengujian regresi untuk variabel Deposito Mudharabah, Tabungan Mudharabah dan Giro Wadi'ah secara bersama-sama terhadap rentabilitas ekonomis menunjukkan nilai Fhitung $=0.305$ dengan signifikansi 0.824, dimana $\mathrm{F}_{\text {tabel }}=19,16$. Jadi $\mathrm{F}_{\text {hitung }}<$ $\mathrm{F}_{\text {tabel. }}$.

Dengan menggunakan batas signifikansi 0.05 , nilai signifikansi tersebut lebih besar dari 0,05. Dengan arah koefisien positif, maka diperoleh hipotesis yang menyatakan bahwa Deposito Mudharabah, Tabungan Mudharabah dan Giro Wadiah secara bersama-sama tidak memiliki pengaruh yang signifikan terhadap rentabilitas ekonomis

Imam Ghozali dalam Runiasari (2008) mengatakan bahwa untuk menunjukkan seberapa jauh pengaruh satu variabel penjelas atau bebas secara individual dalam menerangkan variasi variabel terikat diperlukan pengujian secara parsial. Hasil yang didapat adalah sebagai berikut :

Tabel 10

Hasil Perhitungan Regresi Parsial
\begin{tabular}{|l|r|r|r|r|r|}
\hline \multirow{2}{*}{ Model } & \multicolumn{1}{|c|}{$\begin{array}{c}\text { Unstandardized } \\
\text { Coefficients }\end{array}$} & $\begin{array}{c}\text { Standardized } \\
\text { Coefficients }\end{array}$ & & \\
\cline { 2 - 5 } & \multicolumn{1}{|c|}{ B } & \multicolumn{1}{c|}{ Std. Error } & \multicolumn{1}{c|}{ Beta } & \multicolumn{1}{c|}{ Sig. } \\
\hline 1 (Constant) & -9.456 & 66.720 & & -.142 & .900 \\
deposito mudharabah & .000 & .000 & 1.016 & .798 & .509 \\
tabungan mudharabah & .000 & .001 & -.723 & -.409 & .722 \\
giro wadiah & -.001 & .002 & -.507 & -.312 & .785 \\
\hline
\end{tabular}

Berdasarkan tabel di atas dapat ditulis dalam bentuk persamaan regresi diperoleh persamaan sebagai berikut : $Y=-9.456+0.0 \times 1-0.0 \times 2-0.001$ $\mathrm{X3}$

Dimana :

$\mathrm{Y} \quad=$ Rentabilitas Ekonomis

$\mathrm{X} 1=$ Deposito Mudharabah

$\mathrm{X} 2=$ Giro Wadiah

X3 = Tabungan Mudharabah

Persamaan tersebut diatas mempunyai arti sebagai berikut :

- Jika $\mathrm{X}_{1}$ naik maka $\mathrm{Y}$ akan mengalami kenaikan sebesar 0,000 $\mathrm{X}_{1}$.

- Jika $\mathrm{X}_{2}$ naik maka $\mathrm{Y}$ akan mengalami penurunan sebesar $0,000 \mathrm{X}_{2}$.

- Jika $\mathrm{X}_{3}$ naik maka $\mathrm{Y}$ akan mengalami penurunan sebesar $0,001 \mathrm{X}_{3}$.

Berikut ini akan dijelaskan pengujian masing-masing variabel secara parsial, dimana $t_{\text {tabel }}=2.920$

a. Variabel Deposito Mudharabah Hipotesis

Ho: $\beta 1 \leq 0$ Tidak ada pengaruh positif dan signifikan dari variabel 
Deposito Mudharabah terhadap rentabilitas ekonomis

Ha: $\beta 1>0 \quad$ Semakin besar Deposito Mudharabah yang diterima maka semakin tinggi rentabilitas ekonomis

Hasil pengujian regresi untuk variabel Deposito Mudharabah terhadap Rentabilitas ekonomis menunjukkan nilai $t_{\text {hitung }}=0.798$ dengan nilai signifikansi 0.509 . Dengan menggunakan batas signifikansi 0.05 , nilai signifikansi tersebut lebih besar dari 0.05, maka hipotesis 1 dapat diterima. Dengan demikian Tidak ada pengaruh positif dan signifikan dari variabel Deposito Mudharabah terhadap rentabilitas ekonomis

b. Variabel Tabungan Mudharabah Hipotesis

Ho: $\beta 2 \leq 0$ Tidak ada pengaruh positif dan signifikan dari variabel Tabungan Mudharabah terhadap rentabilitas ekonomis

Ha: $\beta 2>0 \quad$ Semakin besar Tabungan Mudharabah yang diterima maka semakin tinggi rentabilitas ekonomis

Hasil pengujian regresi untuk variabel Tabungan Mudharabah terhadap rentabilitas ekonomis menunjukkan nilai thitung $=-0.409$ dengan signifikansi 0.702 . Dengan menggunakan batas signifikansi 0.05 , nilai signifikansi tersebut lebih besar dari 0,05, maka hipotesis 2 dapat diterima dengan demikian Tidak ada pengaruh positif dan signifikan dari variabel Deposito Mudharabah terhadap rentabilitas ekonomis c. Variabel Giro Wadiah Hipotesis

Ho: $\beta 3 \leq 0$ Tidak ada pengaruh positif dan signifikan dari variabel Giro Wadiah terhadap rentabilitas ekonomis

Ha: $\beta 3>0$ Semakin besar Giro Wadiah yang diterima maka semakin tinggi rentabilitas ekonomis

Hasil pengujian regresi untuk variabel Giro Wadiah terhadap rentabilitas ekonomis menunjukkan nilai $\mathrm{t}_{\text {hitung }}=-0.312$ dengan signifikansi 0.785 . Dengan menggunakan batas signifikansi 0.05 , nilai signifikansi tersebut lebih besar dari 0,05, maka hipotesis 3 dapat diterima dengan demikian Tidak ada pengaruh positif dan signifikan dari variabel Giro Wadiah terhadap rentabilitas ekonomis

\section{BAB V KESIMPULAN DAN KETERBATASAN \\ Kesimpulan}

Penelitian ini menguji pengaruh Dana Pihak Ketiga, yang dalam hal ini dibatasi pada Deposito Mudharabah, Tabungan Mudharabah dan Giro Wadi'ah terhadap Rentabilitas Ekonomis pada PT. Bank Muamalat Indonesia selama periode 2010-2015.

Hipotesis awal pada regresi dan korelasi pada penelitian ini adalah ada pengaruh yang positif dari Dana Pihak Ketiga (yang dibatasi pada Deposito Mudharabah, Tabungan Mudharabah dan giro Wadi'ah) terhadap tingkat Rentabilitas Ekonomis.

Hasil perhitungan dalam regresi liniear berganda Dana pihak ketiga terhadap tingkat rentabilitas ekonomis 
perusahaan menunjukkan bahwa dana pihak ketiga tidak secara signifikan mempengaruhi rentabilitas ekonomis perusahaan. Pengujian Hipotesis dilakukan dengan 2 (dua) uji, yaitu uji hipotesis secara keseluruhan dengan menggunakan uji t.

Hasil dari uji Pancaran Fishier pancaran F (uji F) pada tingkat kepercayaan $95 \%$ atau $\alpha=0,05$ dan derajat kebebasan yang digunakan untuk pembilang (V1) $\mathrm{k}-1=4-1=3$, dan derajat kebebasan untuk penyebut (V2) $\mathrm{n}-\mathrm{k}=6-4=2$, menunjukkan hasil $F_{\text {hitung }}$ sebesar 0,798 sedangkan $F_{\text {tabel }}$ sebesar 19,16. Dengan demikian $\mathrm{F}_{\text {hitung }}<$ $\mathrm{F}_{\text {tabel }}$ yang artinya Dana pihak ketiga terhadap rentabilitas ekonomis secara signifikan diterima.

Sedangkan koefisien determinasi (R2) adalah sebesar $31,4 \%$ yang menunjukkan bahwa dana pihak ketiga tidak secara signifikan mempengaruhi rentabilitas ekonomis perusahaan sehingga dapat disimpulkan bahwa hipotesis awal (Ho) diterima dan hipotesis alternative (Ha) ditolak.

Hasil uji t menunjukkan hasil yang tidak jauh berbeda dengan pengujian secara keseluruhan, yaitu masing-masing variabel dana pihak ketiga yaitu deposito mudharabah, tabungan mudharabah dan giro wadi'ah tidak mempunyai pengaruh terhadap rentabilitas ekonomis perusahaan.

\section{Saran}

Dari kesimpulan penelitian diatas, maka penulis memberikan sedikit saran bahwa :

1. Perusahaan hendaknya meningkatkan pendapatannya, baik pendapatan operasional maupun non operasional sekaligus menatalaksanakan biaya- biaya operasionalnya terutama pada pos-pos administrasi dan umum untuk meningkatkan sumber-sumber dana yang dimilikinya terutama pada Dana Pihak Ketiga yang terdapat pada Perusahaan.

2. Perusahaan melakukan pengawasan dan studi kelayakan yang lebih baik terhadap nasabah peminjam agar dapat menekan peningkatan cadangan penghapusan aktiva produktif.

\section{DAFTAR PUSTAKA}

Algifari. 2000. Analisis Regresi Teori, Kasus dan Solusi. Penerbit BPFE. Yogyakarta

Bambang Riyanto. 2011. Dasar-dasar Pembelanjaan Perusahaan. Yayasan Badan Penerbit Gadjah Mada. Yogyakarta.

Brighaam dan Houston. 2006. Fundamental of Financial Management: Dasar-dasar Manajemen Keuangan. Jakarta: Salemba EmpatSugiyono. 2009. Metode Penelitian Kuantitatif Kualitatif dan $R \& D$ edisi 8. ALFABETA : Bandung.

Ghozali. Imam. 2005 Aplikasi Analisis Multivariat dengan program SPSS. Badan Penerbit Universitas Diponegoro, Semarang.

Indriantoro, Nur dan Supano. Bambang. 2002. Metodologi Bisnis untuk Akuntasni dan Manajemen. BPFE. Yogyakarta.

S. Munawir. 2010. Analisa Laporan Keuangan. Liberty. Yogyakarta

www.idx.co.id 